\title{
All Education is Spiritual and Ergo Homeschooling is Resurging 1
}

\begin{abstract}
All education is spiritual and ergo homeschooling is resurging. Parent-directed, family- and home-based private education schooling - that is, homeschooling - is millennia old and has experienced a notable renascence around the world during the past 40 years. With respect to homeschooling, "Parent-directed means the parents have deliberately chosen to take responsibility for the education of their children, controlling both the education process and the curriculum (course of study). Familybased means the center of educational gravity is the home, with other resources being secondary" (homeschoolingbackgrounder.com, 2020). One of the key reasons that home education is growing is that more parents and more of the general public are recognizing that all education of children deals with values, beliefs, and, ultimately, an overall worldview (Weltanschauung). Because worldview is a comprehensive conception or apprehension of the world, especially from a specific standpoint, it is, de facto, spiritual. This paper shows that all education and schooling is the teaching, training, and indoctrination of children, that the worldwide rebirth of home education came with a focus on spirituality, that empirical evidence shows that all education is spiritual and spirituality is motivating many homeschoolers, and, finally, that scholarly theoretical arguments against homeschooling involve the spiritual.
\end{abstract}

Keywords: homeschooling, home education, spirituality, public school, private school.

\footnotetext{
* National Home Education Research Institute Salem, Oregon, USA. Article received: 30.10.2020; accepted: 30.01.2021.

1 The author thanks all of the donors and contributors and encouragers over the years who have supported the work of the nonprofit organization (NGO) National Home Education Research Institute in Salem, Oregon, USA.
} 


\title{
Duchowy charakter całości edukacji powodem odradzania się edukacji domowej
}

\begin{abstract}
Abstrakt
Każda odmiana edukacji ma „duchowy” charakter, czego konsekwencją jest renesans edukacji domowej. Kierowana przez rodziców, oparta na rodzinie i domu prywatna edukacja - tj. edukacja domowa - ma tysiące lat, a od czterdziestu lat doświadcza zauważalnego renesansu na całym świecie. Oto jego definicja: „Kierowanie przez rodziców oznacza, że dobrowolnie przyjmują oni na siebie odpowiedzialność za edukację swoich dzieci, kontrolując zarówno jej proces, jak i program (treści). Oparcie na rodzinie to wskazanie, że środkiem ciężkości edukacji jest rodzinny dom, a jej środki mają drugorzędne znaczenie" (homeschoolingbackgrounder.com, 2020). Jednym z głównych powodów upowszechniania się edukacji domowej jest to, że coraz większa liczba rodziców i coraz większy segment opinii publicznej uznaje za istotne wartości, przekonania, a ostatecznie ogólny światopogląd (Weltanschauung). Jako że światopogląd jest ogólną koncepcją lub wizją świata, szczególnie z konkretnego punktu widzenia, to de facto ma charakter duchowy. Artykuł ten wykazuje, że cała edukacja i kształcenie są nauczaniem, wdrażaniem i indoktrynacją dzieci, że światowe odradzanie się edukacji domowej dokonuje się z orientacją na duchowość oraz że empiryczne dowody przesądzają o tym, iż całość edukacji jest duchowa, przy czym duchowość motywuje wielu edukatorów domowych, a wreszcie że akademickie, teoretyczne zaledwie argumenty przeciwko edukacji domowej same zdradzają swoiste uduchowienie.
\end{abstract}

Słowa kluczowe: edukacja domowa, duchowość, szkoła publiczna, szkoła prywatna.

\section{Introduction}

All education is spiritual and ergo homeschooling is resurging. Parent-directed, family- and home-based private education schooling - that is, homeschooling - is millennia old and has experienced a notable renascence around the world during the past 40 years. With respect to homeschooling, "Parent-directed means the parents have deliberately chosen to take responsibility for the education of their children, controlling both the education process and the curriculum (course of study). Family-based means the center of educational gravity is the home, with other resources being secondary" (homeschoolingbackgrounder.com, 2020). One of the key reasons that home education is growing is that more parents and more of the general public are recognizing that all education of children deals with values, beliefs, and, ultimately, an overall worldview (Weltanschauung). Because worldview is a comprehensive conception or apprehension of the world, especially from a specific standpoint, it is, de facto, spiritual.

A worldview is spiritual because all conceptions of the world are based on presuppositions, assumptions, or axioms regarding metaphysics, epistemology, and 
axiology. These presuppositions will always, explicitly or implicitly, include addressing things spiritual. Throughout the history of humankind, men and women, boys and girls, have asked one another about, thought about, and written about that which is immaterial and that which makes up the unseen and untouchable aspects of people. The spiritual is defined as "of, relating to, consisting of, or affecting the spirit" (www.merriam-webster.com/dictionary/spiritual) or "Consisting of spirit; not material; incorporeal; as a spiritual substance or being. The soul of man is spiritual" (www.webstersdictionary1828.com/Dictionary/spiritual). Both definitions are based on the concept of spirit. Spirit is "an animating or vital principle held to give life to physical organisms" (www.merriam-webster.com/ dictionary/spirit) or, according to one definition, "The soul of man; the intelligent, immaterial and immortal part of human beings. The spirit shall return to God that gave it" (www.webstersdictionary1828.com/Dictionary/spirit). Those who hold to the Christian worldview embrace the idea that men and women have never been able to not think and talk about the spirit and things that are spiritual because a spiritual Being created men and women in His image. Many non-Christian philosophers also agree that all humans throughout history have considered and pondered the spiritual.

\section{Education and Schooling Involve the Spiritual}

Philosophers of education, more than most professors of education, practitioners of pedagogy, and schooling administrators and bureaucrats, understand that all of the education of children (and adults) involves that which is spiritual or religious (since religion deals, at its core, with the spiritual, things and beings of ultimate reality that are immaterial or not readily seen, and "a personal set or institutionalized system of religious attitudes, beliefs, and practices" (www.merriam-webster.com/ dictionary/religion). No schooling of children can escape the reality that children will be taught spiritual things throughout their education, whether within the sphere of influence of an institutional school or at home. Glenn (1987) carefully showed that schooling virtually always includes both of the objectives of teaching skills useful to economic life and the development of attitudes, loyalties, and values.

While analyzing public/government school textbooks, Nord (1995) found that although the public school texts appeared to ignore religion (e.g., in the sense of there being a supreme being who has authority over humans), a value- and beliefladen worldview permeated the books and was being taught to the state-school students.

There is something like a coherent worldview, a loosely structured set of philosophical commitments, which underlie and give shape to the texts

- at least those texts I reviewed (...) the philosophical commitments that 
define this worldview are the same commitments that support and make sense of the dominant cultural and intellectual institutions of modernity: the knowledge we acquire in the present is more valuable than the wisdom of the past; (...) reason is "deconstructed" into its scientific or narrowly utilitarian components, (...); (...) science and social science provide us with our only true knowledge of the world. By implication, religion is irrelevant to understanding the world (Nord 1995: 159).

Glanzer (1998) provided evidence that the public school curriculum is religious and not religiously neutral. "In other words, textbooks [used in government schools] answer these foundational [philosophical, spiritual] questions in ways that show preferential treatment of secular answers and indirect antagonism of religious perspectives" (Glanzer 1998: 221). Glanzer explained that educators, trying to be "neutral" about religion, promote the "equality of exposure" model in which children are to be exposed to a whole variety of ideological perspectives and stories. He laid out the dissoluteness of this solution:

The major problem with this approach, though, goes much deeper. The "equality of exposure" model treats education less as a search for truths - the learning or disregarding of which might have lifelong or eternal consequences - and more like an ice cream store. Knowledge and ideas are approached not with a sense of importance but as matters of taste (ibidem: 222).

In other words, by this state-school approach, children are taught that each one's own person or spirit, at core - each person's own values and ideas - is god over truth. Each person's wants and desires and decisions reign as alleged truth in his or her own mind and life's actions. This is a spiritual education that the government/public schools give to children.

Philosopher Gordon Clark (1955) observed over one-half century ago in the United States that government elementary and secondary schools were highly religious, as he presented the following.

The strategy of the humanist is to occupy the time and the attention of children to such an extent that they will have no opportunity to hear the Gospel. The public [government, state] schools with their compulsory attendance are to be used for the inculcation of secularism. And those who oppose secularism and who want to give their children Christian instruction are branded as antisocial, undemocratic, and divisive (Clark 1955: 2).

It is accurate and obvious that all schooling and education is the teaching, training, and indoctrination of children. Education teaches; it causes children to know something or to know how to do something. Education trains; it forms children "by 
instruction, discipline, or drill" (www.merriam-webster.com/dictionary/train). Education also indoctrinates; it teaches or instructs children "in rudiments or principles" (www.webstersdictionary1828.com/Dictionary/indoctrinate) or imbues children "with a usually partisan or sectarian opinion, point of view, or principle" (www.merriam-webster.com/dictionary/indoctrinate). All education - state/public/government schooling, private institutional schooling, and homeschooling - teaches, trains, and indoctrinates children. The teaching, training, and indoctrination always include things spiritual, whether such are implicit or explicit in the curriculum and activities of the teacher or system.

\section{Scholars Substantiate Education is Teaching, Training, and Indoctrination}

Various scholars throughout history have shown that education and schooling are essentially the teaching, training, and indoctrination of children that consistently delves into spirituality. Values, beliefs, and presuppositions are constantly imbued to children by educators, whether those are the parents or teachers in a state or private institution. For example, education among the Jews centuries ago, and to this day for most committed Jews, was and is "the training of the individual in the service of God" (Barclay 1959: 11). Whether in reading or arithmetic, "Jewish education was entirely religious education" (ibidem: 13). Education in Sparta, on the other hand, was for "the obliteration of the individual in the service of the state" (ibidem: 49) which led to "horrifying savagery and cruelty" and to the Spartan "way of life [that] was based on slavery" (ibidem: 51) and "it can be seen that there was at least a sense in which Spartan education could become education for murder" (ibidem: 52). Spartan life was spiritual in that it put the alleged needs of the state, the whole of persons in one national identity, as sovereign over the rights or needs of individuals and over the propositions or commands of any supernatural God that might exist. Different from in Sparta, education among the Romans was "the training of the individual in the service of the state" (ibidem: 143).

One more example, amongst many, of how education is always spiritual concerns Christianity. Christians know that "the New Testament is certain that the only training which really matters is given within the home, and that there are no teachers so effective for good or evil as parents are" (ibidem: 236). In addition, Christians in the early church held, like those today, based on the whole counsel of both the Old Testament and the New Testament, that the purpose of education is to bring children up in the discipline or training and instruction of the Lord Jesus Christ (Ephesians 6:4), to preach to them the gospel as God uses that to save them, and then to serve God, and do so all to the glory of the triune God, Father, Son, and Holy Spirit (London Baptist Confession, 1689, Chapter 5, paragraph 5; Chapter 16, paragraph 7). Whether learning to read, write, cipher, sew clothing, weld metals, 
preach the gospel, or know and understand history or science, education for the Christian is all for the spiritual purpose of worshipping the Lord by way of providing for one's family, serving Christ's bride the church, and giving glory to God.

Along this line, Nord (1995) concluded the following after his review of U.S. textbooks:

Indeed, I will argue that at least in its textbooks and formal curriculum students are indoctrinated into the modern (secular) worldview and against religion (Nord 1995: 160).

There is no neutral ground on which to stand in making judgments about content, causality, meaning, and truth. All terrain is contested ground. The natural and social sciences, various philosophies and religions, divide the world up in different and conflicting ways. Philosophical neutrality will inevitably prove to be a will-o'-the-wisp, for all authors approach their subject from within particular worldviews, with philosophical commitments that define for them what counts as important, as knowledge, as reasonable, as true. There is no such thing as a neutral point of view. To write a textbook is to take sides (ibidem: 165).

Children might not know that they are being taught, trained, an indoctrinated but those in power and control over education and systems of schooling know what they are doing. The term molding citizens often arises in literature on education in state/government schools. The molding of children is a spiritual matter.

Time and again, statist individuals and groups have wanted to or actually have controlled children's education with plans to mold them (Lionini 1990). For example, one group of education controllers (i.e., a government General Education Board) saw it as their dream to mold and control the next generation of citizens. This is what they wrote:

In our dream, we have limitless resources and the people yield themselves with perfect docility to our molding hand. The present educational conventions fade from their minds; and, unhampered by tradition, we work our own good will upon a grateful and responsive rural folk. We shall not try to make these people or any of their children into philosophers or men of learning, or of science. We are not to raise up from among them authors, orators, poets or men of letters. We shall not search for embryo great artists, painters, musicians. Nor will we cherish even the humbler ambition to raise up from among them lawyers, doctors, preachers, politicians, statesmen, of whom we now have ample supply. (...) For the task that we set before ourselves is a very simple as well as a very beautiful one: to train these people as we find them for a perfectly ideal life just where they are (...) (Gates 1916: 6). 
Philosopher and theologian Rousas Ruhdoony had been explaining for decades the controlling and molding spiritual nature of state-run schooling. Then in 1982 he presented it this way:

The modern state seeks total power by means of the control, among other things, of two key areas of life, education and economics. Statist control of either is a great moral evil. By controlling education, the state seeks to reshape the minds of future citizens into a predetermined mold. The increasing pattern of totalitarianism is power through control of education (Ruhdoony 1982: 63).

Historian Charles Glenn (1987) has carefully reviewed many aspects of the history of American government schooling. His 1987 piece explicated how the "common school revival" in Massachusetts, "was essentially an effort by a Unitarian/Whig minority - the 'new class' of the day - to reshape [mold] popular beliefs and values after a single pattern. State action was necessary" they argued. The re-molding would, amongst other things, work "by inculcating the beautiful and sublime truths of ethics and natural religion" and protect the rising generation from having the wrong religious beliefs (e.g., beliefs and expressions that are "extreme") (Glenn 1987: 28). These government-school advocates designed to control the spiritual development of children, the next generation of voting and influential citizens.

The classical liberal philosopher Murray Rothbard (1999) explained that every school class casts all the instruction into one uniform mold and thus pushes each child into a mold. "Regardless how the teacher instructs, at what pace, timing, or variety, he is doing violence to each and every one of the children. Any schooling involves misfitting each child into a Procrustean bed of unsuitable uniformity" (Rothbard 1999: 7). Along similar lines, Hager (1999) held that government-school students "are propagandized into the doctrines of the leadership, their thoughts molded to the state's purposes. But even under a 'democratic' regime the state operates manipulatively for its own ends. Those who govern generally like to continue governing" (Hager 1999: 20-21).

More recently, two historians (Carper, Hunt 2007) captured the nature and objectives of those who promoted government-controlled schooling in the United States in the mid-nineteenth century. They put it thus:

(...) educational reformers touted the messianic power of tax-supported, government-controlled schooling. Common schools, they believed, would mold a moral, disciplined, and unified population prepared to participate in American political, economic, and social life. Some reformers went so far as to view the common school as a substitute for the family. Horace Mann, for example, often referred to the state and its schools as "parental". Private schools, on the other hand, were often cast as undemocratic, divisive, and inimical to the public interest (ibidem: 241-242). 
The common/government school advocates not only promoted what they believed was the correct spiritual and religious values-laden education for American children but they also had in mind what they thought was the wrong spiritual and religious education. Overall, these philosophical and political advocates of government schooling won the battle and by about 1900 the majority of U.S. children were attending state-run schools that were full of spiritual education, even if for only a few months per year.

Carper and Hunt (2007), explained the overarching religious and spiritual nature of public/state schooling this way:

In sum, then, we contend that the public school is the functional equivalent of an established church, buttressed with religious language, expected to embrace all people, legitimating and transmitting an orthodoxy or worldview, and underwritten by compulsory taxation (ibidem: 4).

Lest the reader think that the spiritual nature of schooling, especially government/public schooling, is only theoretical, at least one current-day concrete example is due. At the 2019 annual meeting of the American Educational Research Association, with roughly 13.000 attendees, Kristin Gunckel (2019), an assistant professor of science education, explained a lively and student-engaging science activity involving live crawdads (or crayfish). She then proceeded to tell the audience that the problem with the activity was that it teaches children heteronormativity and instead elementary science teachers should be using the spiritual "queer theory lens" in order to "disrupt what is normal". She promoted her religious worldview as being the good and proper one for teaching science to all children in America's government schools.

\section{The Rebirth of Home Education Came with a Focus on Spirituality}

Into the milieu of increasing secularity in American culture in general and in statecontrolled schooling in particular, homeschooling re-emerged in the United States. Several histories of the modern-day homeschool movement have been written and most of them have emphasized the importance of religion in the movement's strength, growth, and stability.

For example, early in the homeschool movement, Bolick (1987) observed that, "Many home schoolers are rigidly traditional and scrupulously law-abiding, while others are long-time practitioners of civil disobedience. Some are fervently religious and have removed their children from mainstream schools because they are too secular, while others are nonbelievers who consider the public schools too 
religious" (Bolick 1987: 84). Later, Stevens (2001) "goes behind the scenes of the homeschool movement and into the homes and meetings of home schoolers. What he finds are two very different kinds of home education - one rooted in the liberal alternative school movement of the 1960s and 1970s and one stemming from the Christian day school movement of the same era" (Princeton University Press 2001). Stevens offered new insights and generally accurate and evenhanded portrayals of the major philosophical and pedagogical camps within the homeschool movement, including the strong value-driven and spiritual motivations of both the "liberals" and Christians involved. The importance of religious concepts and objectives of a large portion of homeschoolers continues to be apparent to this day (e.g., Ray 2017a).

Literature by and aimed more at the layperson has clearly shown the conceptually spiritual roots of a major portion of the homeschool community and movement. For example, theologian Dr. Paul Calvin Lindstrom founded Christian Liberty Academy Satellite Schools in 1967 and they have helped over 100.000 families begin or persevere in homeschooling. CLASS explains that "God requires that His children be given a distinctively Christian education. Every subject is to be studied with the purpose of discovering the God-given meaning contained in it" (CLASS Homeschools 2020). One of the first and best-known women authors in the homeschool movement was Mary Pride, a Christian. A former feminist, she explained (Pride 1985) that spiritual discipling of children, by both adults and peers, is always occurring during teaching or schooling, and that, "As I read the Scriptures, public education is not a legitimate function of government at all" (ibidem: 98).

Other major voices regarding spirituality and religion in both the genre of books and conferences at the beginning of the current homeschool movement were Samuel Blumenfeld, Gregg Harris, Richard Wheeler, and Ray Ballmann. Blumenfeld wrote that, "The humanist worldview now dominates American public education so completely, that the only escape is the private school or the home school" (Blumenfeld 1984: 261). Harris (1988) argued that home-based education is the preferred method of educating children, that it is a return to a historical practice, and that it is an acceptance of parents' God-given responsibility, and beginning in the early 1980s, Harris presented Christian Life Workshops across the United States. One of the best-known speakers at homeschool conferences for decades was Richard "Little Bear" Wheeler who wrote the book, Warning: Public Schools Aren't for Christians: A Biblical Perspective on the Dangers of Public Schools (1997); it was thoroughly spiritual in its orientation and message.

The strong emphasis on the soul of man, that is, the intelligent, immaterial, and immortal part of human beings, and the biblical God continues to be a core element of the conferences, books, social media conversations, and discussions of a major portion of the homeschool community. Evidence of this can be seen in books such as Education: Does God Have an Opinion, by one of the most popular Christian 
homeschool speakers, Israel Wayne (2017) and Abolition: Overcoming the Christian Establishment on Education, by attorney Kevin Novak (2016) and in one of the largest-circulation and longest-standing homeschool magazines, The old Schoolhouse (2020).

\section{Empirical Evidence Shows that all Education is Spiritual and Motivating Many Homeschoolers}

The U.S. Department of Education has studied homeschooling families in several nationwide surveys (2019). During the last two iterations of the sampling, spiritual reasons for homeschooling ranked highly. The "desire to provide religious instruction" was "important" to $64 \%$ of the parents in 2012 and to $51 \%$ in 2016, and it was the "most important" for $17 \%$ in 2012 and $16 \%$ in 2016 . In a similar vein, the "desire to provide moral instruction" was "important" to 77\% in 2012 and 61\% in 2016, and the "most important" reason for 5\% in 2012 and 2016. Other reasons listed by the report included concepts (e.g., "concern about environment of other schools") that might encompass the spiritual or religious to some degree.

Many other studies across decades have found clear empirical evidence that spiritual concerns and teaching specific philosophical and religious worldviews to children are key reasons that parents choose homeschooling. Examples of the empirical research are Van Galen (1987), Mayberry, Knowles, Ray, and Marlow (1995), and Ray (2004).

\section{Scholarly Theoretical Arguments Against Homeschooling Involve the Spiritual}

Various scholars have argued against homeschooling or for more government control of homeschooling because they are worried about the spiritual implications of parents directing their own children's education. A few examples will suffice.

Apple (2000) approached homeschooling in general and presented that he did not want to give his wholehearted support to homeschooling but he then quickly switched to telling his readers that his main concern or worry was parents who have "made their decision [to homeschool] based on religious convictions" and a large proportion have done so (Apple 2000: 257). Apple, a critical theorist, was clearly opposed to the biblical and Christian values and beliefs that a "large proportion" of homeschool parents were teaching to their children and wanted, instead, these children to be in government/public schools where they could be taught the right values and beliefs, those which Apple held and promoted to the world, and opposed to Christian teachings. 
Reich (2002) argued that it is wrong for parents to be in charge of what values and beliefs, that is, the core of spiritual education, are taught to school-age children. He firmly promoted the concept that the state must control a child's education, even if homeschooled, and coerce the parents to teach their children "values and beliefs", spirituality or religion, with which the parents disagree.

Very recently, law professor Bartholet (2020) argued for strong state control over private homeschooling. It was clear that Bartholet's overall theme was "anti-conservative and anti-religious" (i.e., anti-Christian values and beliefs) (DeAngelis 2020). Bartholet wanted all homeschool children to have imbued to or inculcated in them a different spirituality from what she imagined Christian parents were teaching.

Going a step further than the state regulating homeschooling more to control the teaching of values and beliefs, Fineman (2009: 14) argued that society should not take the risk that parents or private schools might "impose hierarchical or oppressive beliefs on their children" Therefore, the state should ban all private schooling and homeschooling and force all children to attend public/government schools.

After Fineman (2009) and before Bartholet (2020), Hasson (2012) succinctly summed up the battle over the spiritual nature of education and the increasingly heated debates about parent-directed home-based and family-based private homeschooling education. Here is how she put it:

Against this backdrop of change - as homeschooling stakes a favorable claim on public opinion and the number of homeschooling families soars - the public conversations about homeschooling have changed as well. These conversations, however, increasingly reflect conflicts over values, ideologies, and worldviews more than they reflect differences over educational pedagogy, practice, or outcomes. (...) The common thread running through these criticisms [by "progressive theorists"] seems to be the belief that the children of religious, usually Christian, homeschoolers will be less capable of functioning as autonomous citizens in a democratic society (...) (Hasson 2012: 11-12).

Hasson was correct. For decades, the research base has shown that homeeducated children have been performing at least as well as institutional public school children in terms of learner outcomes. Ray's (2017c) review of research revealed that overall, $78 \%$ of the 45 peer-reviewed studies found that the homeschooled students or graduates performed significantly better than their conventional or institutional school peers in terms of academic achievement, social, emotional, and psychological development, and success into adulthood (including in post-secondary education, college/university). Another review of research (Ray $2017 \mathrm{~b}$ ) that included more than just peer-reviewed research also found the homeschooled to be performing, on average, better than those who attend 
institutional schools. In other words, despite the fact that the home educated are doing well in terms of learning their academic subjects and important skills, a rising number of negative critics are not concerned about academic learning but are, instead, pushing for their preferred spiritual, religious, and political education being given to home-educated children.

\section{Concluding Thoughts}

All education of children is spiritual and it has been thus for millennia. All those who vie for control over the education of children are vying over values and beliefs, that is worldviews. They are competing with one another about which ones are true, correct, or good, and they are struggling over which ones will be taught to children.

When parent-directed, family- and home-based private education schooling had become close to extinct in the United States by the 1970s, close to no scholars or others studied it or wrote about it. When homeschooling grew to involve hundreds of thousands of school-age children, advocates of parent-directed education became enthusiastic while professional educators and unions of government-certified public/state school teachers began to claim that homeschooling could not provide as good an education as could government/public schools, and a few scholars voiced some concerns. As homeschooling grew in acceptance by the general public and surpassed the one million-student mark, an increasing number of scholars and activists began to publish more articles criticizing homeschooling and calling for more government control over it, and promoting government policies that would enact more state control.

These calls for state control over private home education clearly tend to come from scholars and policymakers who believe in worldviews of statism, socialism, neo-Marxism, critical theory, feminism, "progressivism", "liberalism", LGBTQIA-ism, atheism, agnosticism, or others that are opposed to classical liberalism, libertarianism, U.S. constitutionalism, mono-theism, and Christianity. Some of those who push for state control over homeschooling accuse homeschool parents of thinking that they "own" the children but the irony of this claim is that it comes from those who implicitly or arguably think that they (as a nebulous group) or the state "own" the children. Calls for government dominance over parent-led private home-based education do not, however, affect only so-called conservative and Christian parents and children. Any call for state control over homeschooling is also a call for dominance and control over all agnostic, atheist, humanist, Jewish, metaphysical naturalist, Mormon, Muslim, New Age, Roman Catholic, and any other-worldview parents who believe that they, and not the state, should have first and final authority over their children's education. 
And this line of thinking must be taken one step further. All persons who value and believe in freedom of religion and conscience, not just those involved in homeschooling, should be attuned here. The call for the state, or a select group of scholars or elites, to have hegemony over children's education also applies to private institutional schooling. It is philosophically consistent for those demanding state dominance over home education to also demand the dominant social, cultural, and ideological influence over private institutional schools, whether secular, Catholic, Lutheran, Jewish, New Age, or Muslim. Kunzman (2009: 328) made the extremely important admission, as all who argue for state control over homeschooling should, that state control of homeschooling (as defined in this article) logically argues for state control of all "nonpublic" (i.e., private) education/schooling. This should cause great concern amongst all advocates of freedom of religion and freedom of conscience in all nations and all advocates of the freedom of expression and operation of private schools, that is, education. It should be remembered that, historically, it was the National Socialists (Nazis) and Hitler of Germany who "banned all forms of private education precisely to achieve philosophical unity" (Farris 2013: 402), that is, to control children's values, beliefs, and worldview. Germany continues, to this day, to ban homeschooling and in this way tries to control a substantial portion of the spiritual development of children.

All education is spiritual and those who want the state and themselves to control the values and beliefs imbued to and inculcated in others' children have been fighting for control for millennia. As homeschooling has grown and continues to grow in nations around the world, this struggle for control over children's spiritual education will continue. At the core of homeschooling is the essential presupposition that parents, who have more love and concern for their own children than any collective of power called the state (or government) can ever have, should guide and control the education of their own children. Those scholars and policymakers who believe in their own worldviews and spirituality and want those to control the education of children have a large task at hand to turn the tide of the growing modern homeschool movement. The battle over the education - which is always spiritual - of children's minds and hearts will continue until the end of all earthly things.

\section{References}

Apple, M. W. (2000) The cultural politics of home schooling, "Peabody Journal of Education" 75 (1, 2): 256-271.

Barclay, W. (1959) Train up a child: Educational ideals in the ancient world, Philadelphia, PA, The Westminster Press.

Blumenfeld, S. L. (1984) N.E.A.: Trojan horse in American Education, Boise, ID, The Paradigm Company 284. 
Bolick, C. (1987) The home schooling movement, "The Freeman: Ideas on Liberty", 37 (3): 84-89.

Carper, J. C., Hunt, T. C. (2007) The dissenting tradition in American education, New York, NY, Peter Lang Publishing, Inc.

Farris, M. (2013) Tolerance and liberty: Answering the academic left's challenge to homeschooling freedom, "Peabody Journal of Education", 88 (3): 393-406.

Fineman, M. A. (2009) Taking children's interests seriously in: What is right for children? The competing paradigms of religion and human rights, M. Albertson Fineman, K. Worthington (eds.), Burlington, VT, Ashgate Publishing Company: 229-237.

Glanzer, P. (1998) Religion in public schools: In search of fairness, "Phi Delta Kappan”, 80 (3): 219-222.

Glenn, Ch. L. (1987) "Molding" citizens in: Democracy and the renewal of public education, R. J. Neuhaus (ed.), Grand Rapids, MI, William B. Eerdmans Publishing Company: 25-56.

Gunckel, K. L. (2019) Repairing elementary school science, Paper presented at the Annual Meeting of the American Educational Research Association, April 5, 2019, Toronto, Canada.

Hager, D. (1999, September) The central fallacy of public schooling, "The Freeman", 49 (9): 20-23.

Harris, G. (1988) The Christian home school, Brentwood, TN, Wolgemuth and Hyatt, Publishers, Inc.

Hasson, H. M. R. (2012) The Changing Conversation around Homeschooling: An Argument for More Data and Less Ideology, "University of St. Thomas Journal of Law and Public Policy", 7, 1 (2012-2013): 1-23.

Kunzman, R. (2009) Understanding homeschooling: A better approach to regulation, "Theory and Research in Education", 7 (3): 311-330.

Mayberry, M., Knowles, J. G., Ray, B. D., Marlow, S. (1995) Home schooling: Parents as educators, Newbury Park, CA, Corwin Press (of Sage Publ.).

Nord, W. A. (1995) Religion and American education: Rethinking a national dilemma, Chapel Hill, NC, The University of North Carolina Press.

Novak, K. (2016) Abolition: Overcoming the Christian establishment on education, Forest, VA, Deconstructing the Coliseum. 
Pride, M. (1985) The way home: Beyond feminism, back to reality, Westchester, IL, Crossway Books.

Ray, B. D. (2004) Home educated and now adults: Their community and civic involvement, views about homeschooling, and other traits, Salem, OR, National Home Education Research Institute, www.nheri.org

Ray, B. D. (2017a) A description and brief history of home schooling in America in: Handbook of School Choice, R. A. Fox, N. K. Buchanan (eds.), Hoboken, NJ, John Wiley and Sons, Inc.: 329-343.

Reich, R. (2002) Testing the boundaries of parental authority over education: The case of homeschooling in: Political and Moral Education, NOMOS XLIII, S. Macedo, Y. Tamir (eds.), New York, New York University Press.

Rushdoony, R. J. (1982) Larceny in the heart: The economics of Satan and the inflationary state [first published under the title The Roots of Inflation], Vallecito, CA: Ross House Books.

Stevens, M. L. (2001) Kingdom of children: Culture and controversy in the homeschooling movement, Princeton, NJ: Princeton University Press.

Van Galen, Jane A. (1987) Explaining home education: Parents' accounts of their decisions to teach their own children, "The Urban Review", 19 (3); 161-77.

Wayne, I. (2017) Education: Does God have an opinion?, Green Forest, AR: Master Books.

Wheeler, R. "Little Bear" (1997) Warning: Public schools aren't for Christians: A Biblical Perspective on the Dangers of Public Schools, Published by and available from Mantle Ministries, 28 Still Ridge, Bulverde TX 78163.

\section{Online sources}

Bartholet, E. (2020) Homeschooling: Parent rights absolutism vs. child rights to education and protection, "Arizona Law Review", 62 (1), https://arizonalaw review.org/homeschooling-parent-rights-absolutism-vs-child-rights-to-educationprotection/ [date accessed: 30.04.2020].

Clark, G. H. (May-June 2009) (1955, August 17, delivered as a public address). The Reformed Faith and the Westminster Confession, "The Trinity Review", http://trinityfoundation.org/journal.php?id=263 [date accessed: 26.06.2020].

CLASS Homeschools (2020), https://www.homeschools.org/godly-education [date accessed: 30.09 .2020$]$. 
DeAngelis, C. A. (2020) Elites go to war on homeschooling - just when everyone's doing it, https://www.cato.org/publications/commentary/elites-go-war-homeschoolingjust-when-everyones-doing-it [date accessed: 30.09.2020].

Gates, F. T. (1916) The country school of to-morrow, https://archive.org/details/ countryschoolof00gate/page/n1/mode/2up [date accessed: 7.04.2020].

Homeschoolingbackgrounder.com. (2020), https://homeschoolingbackgrounder.com/ [date accessed: 29.09.2020].

Lionini, P. (1980) (first printing 1980; copyright 1993) The Leipzig connection: The systematic destruction of American education, Sheridan, Oregon: Heron Books, https://archive.org/stream/LionniTheLeipzigConnectionSystematicDestructionOfA mericanEducation1993/Lionni\%20-\%20The\%20Leipzig\%20Connection\%20\%20Systematic\%20Destruction\%20of\%20American\%20Education $\% 20 \% 281993 \%$ 29_djvu.txt [date accessed: 7.04.2020].

London Baptist Confession (1689), https://www.arbca.com/1689-confession; date accessed: 30.09.2020].

Princeton University Press (2001), http://pup.princeton.edu/titles/7135.html [date accessed: 6.09.2001].

Ray, B. D. (2017b) A review of research on Homeschooling and what might educators learn?, "Pro-Posições", 28 (2), http://dx.doi.org/10.1590/1980-6248-2016-0009 [date accessed: 11.06.2020, 21.11.2018].

Ray, B. D. (2017c) A systematic review of the empirical research on selected aspects of homeschooling as a school choice, "Journal of School Choice: International Research and Reform", 11 (4): 604-621 https://doi.org/10.1080/15582159.2017.1395638 [date accessed: 12.12.2017].

Rothbard, M. N. (1999; originally published 1971 in magazine "The Individualist") Education: Free and compulsory. Auburn, AL: Ludwig von Mises Institute; http://mises.org/library/education-free-and-compulsory-1 [date accessed: 8.01.2015].

The Old Schoolhouse (2020), www.theoldschoolhouse.com; date accessed: 30.09.2020].

United States Department of Education (2019, December) Homeschooling in the United States: Results from the 2012 and 2016 Parent and Family Involvement Survey (PFI-NHES: 2012 and 2016), https://nces.ed.gov/pubs2020/2020001.pdf [date accessed: 30.09.2020]. 